\title{
Analisis Spasial Tingkat Pengangguran Terbuka di Provinsi Jawa Barat
}

\author{
Wika Gessan Septiyanto $^{\mathrm{a}, *}$, \& Ema Tusianti ${ }^{\mathrm{a}}$ \\ ${ }^{a}$ Badan Pusat Statistik
}

\begin{abstract}
The open unemployment rate (TPT) of West Java Province is still above the national rate and has not been able to reach the targets of the Regional Medium-Term Development Plan (RPJMD) and the National Medium-Term Development Plan (RPJMN). Besides, the TPT distribution among regencies also tends to clustering in the western region with the higher rate. The aim of this study is to identify the factors that determine the TPT by considering the effects of neighborhood. This study utilizes spatial regression method by using panel data and some alternative statistical models. The model used is the fixed effect spatial autoregressive model. This study finds that the factors that determine the TPT are Labor Force Participation Rate (TPAK), Municipal Minimum Wage $(U M K)$ and the percentage of labor force in manufacturing sector.
\end{abstract}

Keywords: unemployment rate; panel data, spatial regression; fixed effect spatial autoregressive model; West Java

\begin{abstract}
Abstrak
Tingkat Pengangguran Terbuka (TPT) Provinsi Jawa Barat masih berada di atas angka nasional dan hingga saat ini belum dapat mencapai target Rancangan Pembangunan Jangka Menengah Daerah (RPJMD) dan Rancangan Pembangunan Jangka Menengah Nasional (RPJMN). Selain itu, TPT di Provinsi Jawa Barat cenderung mengelompok dengan TPT lebih tinggi di bagian barat. Oleh karena itu, tujuan dari penelitian ini adalah untuk mengidentifikasi faktor-faktor yang memengaruhi TPT di Provinsi Jawa Barat dengan mempertimbangkan efek ketetanggaan. Metode yang digunakan adalah metode regresi spasial dengan data panel. Model yang terpilih adalah fixed effect spatial autoregressive model. Faktor yang memengaruhi TPT di Provinsi Jawa Barat dengan mempertimbangkan efek ketetanggaan adalah Tingkat Partisipasi Angkatan kerja (TPAK), Upah Minimum Kabupaten (UMK), dan persentase tenaga kerja sektor industri.
\end{abstract}

Kata Kunci: Tingkat Pengangguran Terbuka (TPT); data panel; regresi spasial; fixed effect spatial autoregressive model; Provinsi Jawa Barat

Kode Klasifikasi JEL: C31; E24; J64

*Penulis Korespondensi: Badan Pusat Statistik (BPS) Kabupaten Bulukumba, Jln. A. Yani No. 18, Caile, Ujung Bulu, Bulukumba, Sulawesi Selatan. E-mail: wikags@gmail.com. 


\section{Pendahuluan}

Pertumbuhan ekonomi adalah suatu ukuran kuantitatif yang menggambarkan perkembangan perekonomian dalam tahun tertentu dibanding dengan tahun sebelumnya (Sukirno, 2006). Tenaga kerja adalah faktor penting dalam meningkatkan pertumbuhan ekonomi. Menurut Todaro (1998) dalam Althofia dan Agustina (2015) pendidikan dan kesehatan merupakan faktor utama dalam membentuk modal manusia yang berkualitas. Modal manusia yang berkualitas dapat meningkatkan produktivitas tenaga kerja. Tingkat pendidikan dan kesehatan yang semakin meningkat akan berdampak pada kualitas tenaga kerja yang semakin baik.

Jika dilihat dari Angka Harapan Hidup (AHH), Provinsi Jawa Barat termasuk ke dalam lima provinsi dengan AHH tertinggi di Indonesia. Selain itu, rata-rata lama sekolah di Provinsi Jawa Barat dari tahun 2013-2017 selalu mengalami peningkatan. Jika dibandingkan degan nasional, laju pertumbuhan rata-rata lama sekolah di Provinsi Jawa Barat terlihat lebih tinggi.

Dari tahun 2013 sampai tahun 2017 laju IPM di Provinsi Jawa Barat mampu melebihi laju IPM nasional. Hal ini menunjukkan adanya upaya yang nyata dari Pemerintah Provinsi Jawa Barat untuk meningkatkan modal manusia. Namun, kondisi yang meningkat tersebut belum mampu mengurangi masalah pengangguran. Secara umum Tingkat Pengangguran Terbuka (TPT) di Provinsi Jawa Barat mengalami penurunan. Namun, penurunan ini terbilang sangat lambat. Di samping itu, angkanya masih di atas delapan persen, masih jauh di atas angka nasional yang sebesar enam persen. Selain itu, tingkat pengangguran di Provinsi Jawa Barat juga belum mampu memenuhi target yang ditentukan daerah.

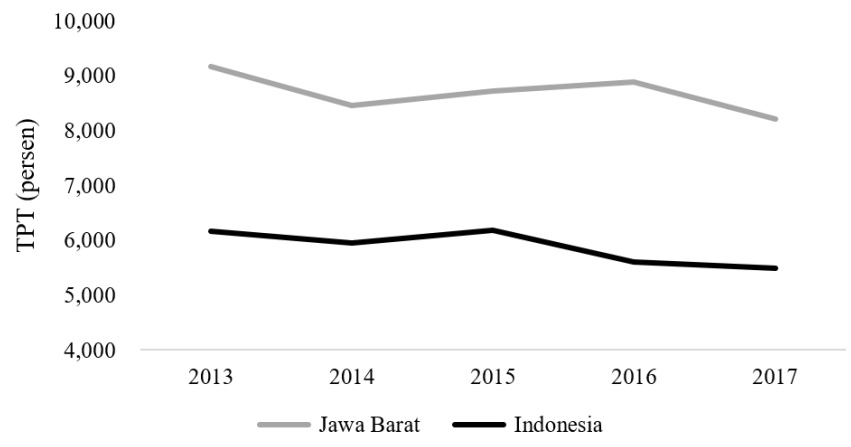

Gambar 1: Tingkat Pengangguran Terbuka (TPT) Provinsi Jawa Barat dan Indonesia Tahun 2013-2017

Sumber: Badan Pusat Statistik (diolah)

Provinsi Jawa barat merupakan salah satu provinsi dengan jumlah penduduk terbesar di Indonesia, tetapi masih memiliki tingkat pengangguran yang tinggi. Berdasarkan data BPS, pada Februari 2017, Provinsi Jawa Barat menduduki 
peringkat kedua dengan TPT tertinggi setelah Provinsi Kalimantan Timur. Jika dilihat dari grafik di atas, TPT di Provinsi Jawa Barat berada pada kisaran 8-9 persen dengan kecenderungan yang menurun dalam periode penelitian dengan laju penurunan yang lebih lambat dari nasional. Selain itu tingkat pengangguran di Provinsi Jawa Barat masih jauh dari target yang ditetapkan pemerintah daerah. Hal ini menunjukkan Provinsi Jawa Barat masih belum maksimal dalam pengentasan pengangguran dibanding dengan provinsi-provinsi lainnya.

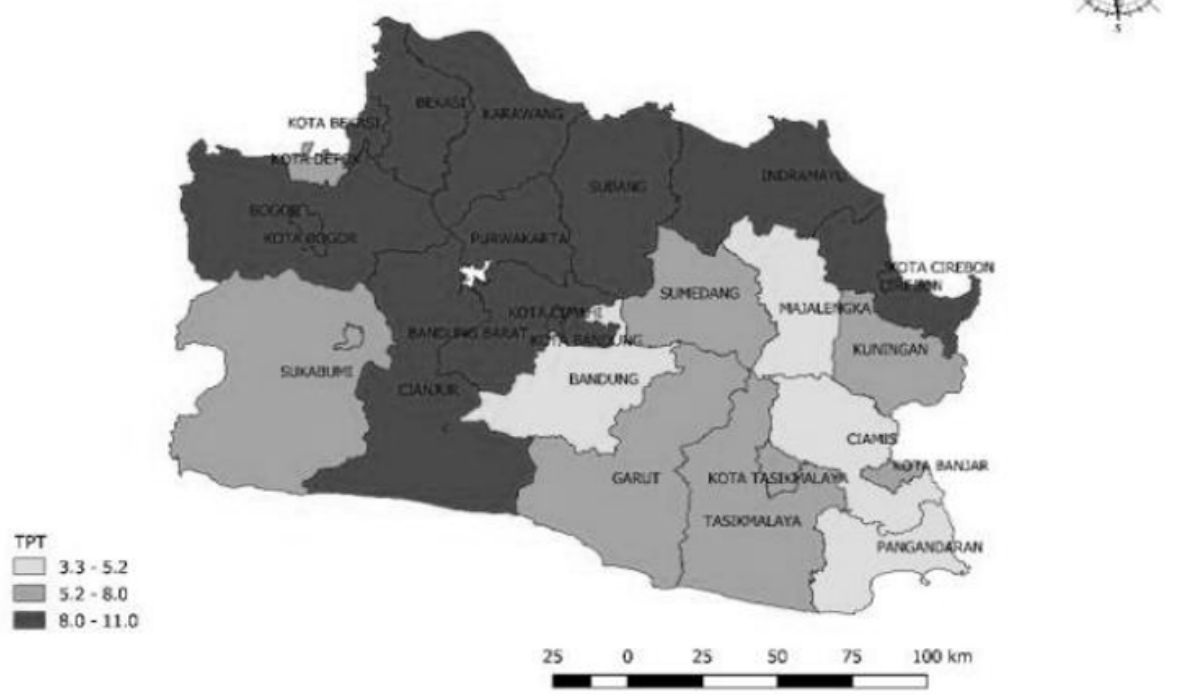

Gambar 2: TPT Provinsi Jawa Barat Menurut Kabupaten atau Kota Tahun 2017 Sumber: Badan Pusat Statistik (diolah)

Jika dilihat dari peta tematik di atas, tingkat pengangguran Provinsi Jawa Barat cenderung mengelompok di bagian barat dengan nilai lebih besar dan di bagian timur dengan nilai lebih rendah. Menurut Elhorst dalam Shekhar et al. (2017) perbedaan nilai di suatu wilayah disebabkan karena setiap daerah memiliki norma, nilai tenaga kerja maupun tingkat kejahatan yang berbeda dan jika mengabaikan efek spasial akan meningkatkan resiko estimator bias. Hukum I Tobler, menyatakan bahwa segala sesuatu yang saling berdekatan memiliki pengaruh yang lebih besar daripada yang jauh. Tingkat pengangguran yang tinggi di suatu daerah menyebabkan penduduknya akan mencari daerah yang memiliki kesempatan kerja yang lebih besar, selain itu upah tinggi yang ditawarkan akan menarik penduduk untuk bekerja di daerah tersebut (Jurajda \& Terrell, 2009). Pengelompokan dalam suatu wilayah dapat terjadi karena adanya pemusatan ekonomi di wilayah-wilayah tertentu. Teori ekonomi geografi 
baru berfokus pada adanya mekanisme kausalitas sirkular yang menjelaskan pemusatan ekonomi dalam suatu wilayah (Krugman \& Venables dalam Martin \& Ottaviano, 2001). Kausalitas sirkular tersebut berasal dari adanya variasi konsumsi produksi. Pengelompokan dalam tingkat pengangguran di Provinsi Jawa Barat mengindikasikan adanya pengaruh ketetanggaan dalam tingkat pengangguran di Provinsi Jawa Barat.

Oleh karena itu, penelitian ini bertujuan untuk melihat gambaran atau pola persebaran maupun faktor-faktor yang memengaruhi tingkat pengangguran terbuka di Provinsi Jawa Barat dengan mempertimbangkan pengaruh ketetanggaan. Hasil dari penelitian ini diharapkan dapat digunakan oleh pemerintah daerah setempat sebagai salah satu acuan ataupun pertimbangan terkait pengentasan pengangguran di Provinsi Jawa Barat. Hipotesis dalam penelitian ini adalah terdapat efek spasial dalam tingkat pengangguran di Provinsi Jawa Barat dan variabel bebas yang digunakan berpengaruh signifikan terhadap variabel terikatnya. Penelitian ini merupakan salah satu dari beberapa penelitian yang sudah dilakukan baik terkait dengan variabel terikatnya ataupun regresi spasial yang digunakan, namun dengan lokasi, periode waktu maupun variabel bebas yang berbeda. Secara umum studi yang sudah dilakukan peneliti sebelumnya menghasilkan beberapa variabel signifikan yang berbeda. Isnayanti dan Ritonga (2017) menemukan bahwa pertumbuhan ekonomi dan upah minimum berpengaruh signifikan terhadap tingkat pengangguran, Mahihody et al. (2017) menemukan bahwa IPM berpengaruh signifikan terhadap tingkat pengangguran, dan Astuti et al. (2017) menemukan bahwa Tingkat Partisipasi Angkatan Kerja (TPAK) berpengaruh positif terhadap tingkat pengangguran.

\section{Metode Penelitian}

\subsection{Metode Pengumpulan Data}

Penelitian ini menggunakan data sekunder dari Badan Pusat Statistik (BPS) Provinsi Jawa Barat. Periode waktu yang digunakan dalam penelitian ini adalah tahun 2013 sampai dengan tahun 2017 dengan 27 objek penelitian yang meliputi seluruh kabupaten/kota di Provinsi Jawa Barat. Variabel yang digunakaan antara lain TPT (persen), pertumbuhan ekonomi (persen), IPM (indeks), TPAK (persen), UMK (juta rupiah) dan tenaga kerja industri (persen).

\subsection{Metode Analisis}

Metode analisis yang digunakan dalam penelitian ini adalah regresi spasial panel. Penimbang ketetanggaan untuk melihat daerah yang menjadi tetangganya digunakan penimbang queen order 1 . Sehingga daerah yang menjadi tetangga adalah daerah yang langsung berbatasan dengan daerah lainnya. Dalam pembuatan peta tematik digunakan metode natural breaks untuk membagi variabel ke dalam tiga kategori, yaitu rendah, sedang, dan tinggi. 
Adapun urutan pengerjaan dalam analisis spasial panel yaitu menentukan weight untuk mengetahui ketetanggaan antarwilayah, melakukan uji Moran I, uji LISA, uji LM SAR dan LM SEM, uji Hausman, estimasi parameter dengan model terbaik, uji asumsi klasik, uji kesesuaian model (goodness if Fit) dan melakukan analisis dan interpretasi. Dalam penelitian ini model spasial panel secara umum adalah sebagai berikut:

$$
\begin{aligned}
\ln (T P T)_{i t}= & \lambda \sum_{j=1}^{N} w_{i j} \ln (T P T)_{j t}+\beta_{1} \ln (\text { Pert_eko })_{i t}+\beta_{2} \ln (I P M)_{i t}+\beta_{3} \ln (T P A K)_{i t} \\
& +\beta_{4} \ln (\text { UMK })_{i t}+\beta_{5} \ln (I D S)_{i t}+\hat{\mu}_{i}+\rho \sum_{j=1}^{N} w_{i j} u_{i t}+\varepsilon_{i t}
\end{aligned}
$$

dengan $T P T_{i t}$ adalah Tingkat Pengangguran Terbuka kabupaten/kota ke- $i$ dan periode ke- $t ; \lambda$ adalah koefisien spasial autoregressive lag; $w_{i j}$ adalah penimbang observasi ke- $i$ dan ke- $j$; IPM $i t$ adalah Indeks Pembangunan Manusia kabupaten/kota ke- $i$ dan periode ke-t; TPAK $i t$ adalah Tingkat Partisipasi Angkatan Kerja kabupaten/kota ke- $i$ dan periode ke-t; Pert_eko $o_{i t}$ adalah pertumbuhan ekonomi kabupaten/kota ke- $i$ dan periode ke- $t$; $U M K_{i t}$ adalah Upah Minimum Kabupaten/kota ke- $i$ dan periode ke-t; IDS $S_{i t}$ adalah share tenaga kerja sektor industri kabupaten/kota ke- $i$ dan periode ke- $t ; \rho$ adalah koefisien spasial error; $\beta_{k}$ adalah koefisien regresi variabel ke- $k$; $\hat{\mu}_{i}$ adalah efek spesifik spasial wilayah ke- $i$; dan $\varepsilon_{i t}$ adalah error wilayah ke- $i$ dan periode ke- $t$.

\section{Hasil dan Pembahasan}

\subsection{Gambaran Umum TPT dan Faktor yang Memengaruhinya di Provinsi Jawa Barat}

Secara umum, tingkat pengangguran Provinsi Jawa Barat pada periode penelitian mengalami penurunan. Namun penurunan yang dialami masih lambat. Jika dilihat perbandingan kabupaten/kota tahun 2013 dan 2017, Kabupaten Bandung memiliki penurunan tingkat pengangguran yang signifikan yaitu dari 10 persen menjadi 3 persen. Hal ini disebabkan karena upaya pemerintah daerah dalam menurunkan pengangguran, yang salah satunya dengan pembangunan Balai Latihan Kerja (BLK) di tingkat kecamatan. Sementara itu, peningkatan pengangguran yang paling besar terdapat di Kabupaten Bekasi. Peningkatan tersebut dari angka 7 persen menjadi 11 persen. Hal ini terjadi karena Kabupaten Bekasi merupakan kawasan industri dengan nilai upah yang tinggi.

Dari Gambar 3, dapat dilihat bahwa persebaran IPM cenderung merata, didominasi dengan pola bulatan sedang dan bulatan besar yang menandakan bahwa nilai IPM di Provinsi Jawa Barat mayoritas berada pada kategori sedang dan tinggi. Terdapat dua kota yang masuk dalam kategori IPM sangat tinggi yaitu Kota Bekasi dan Bandung yang ditandai dengan pola bulatan terbesar. 


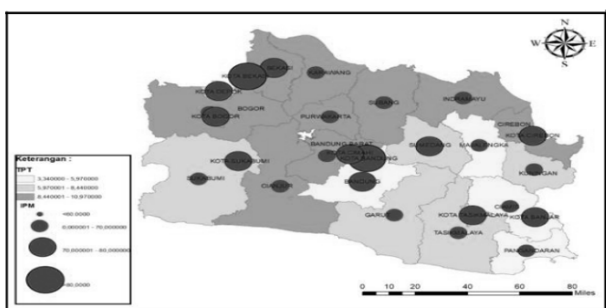

Hubungan TPT dengan IPM

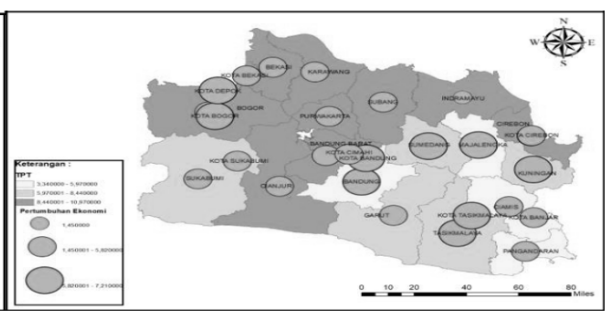

Hubungan TPT dengan pertumbuhan ekonomi

Gambar 3: Hubungan TPT dengan Variabel Bebasnya Tahun 2017 Sumber: Badan Pusat Statistik (diolah)

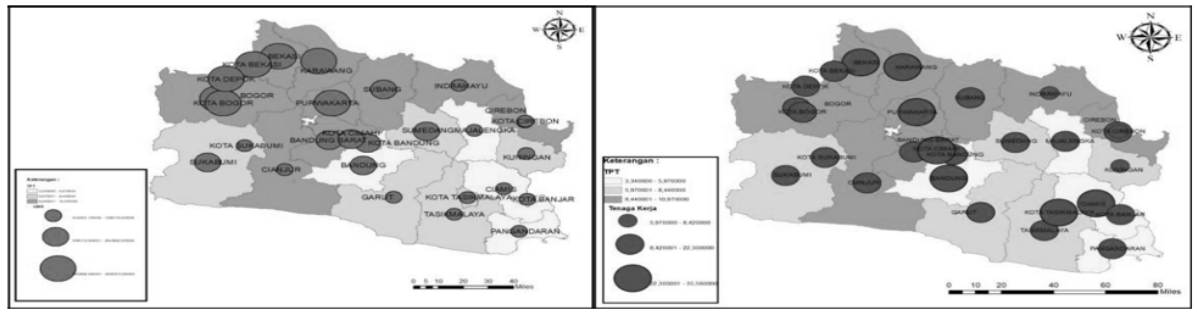

Hubungan TPT dengan UMK Hubungan TPT dengan share tenaga kerja industri

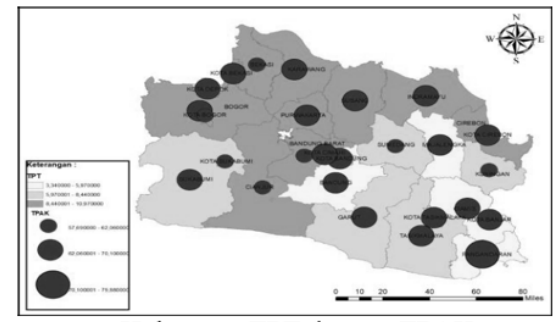

Hubungan TPT dengan TPAK

Gambar 4: Hubungan TPT dengan Variabel Bebasnya Tahun 2017

Sumber: Badan Pusat Statistik (diolah)

Seperti halnya IPM, persebaran laju PDRB cenderung merata dengan kategori rendah, sedang, dan tinggi. Hanya tiga wilayah yang masuk dalam kategori sangat tinggi yaitu Majalengka, Kota Bandung dan Kota Depok.

Dari Gambar 4, wilayah bagian barat cenderung memiliki UMK lebih tinggi daripada bagian timur. Kota Bekasi, Kabupaten Bekasi, dan Kabupaten Karawang menjadi wilayah dengan UMK tertinggi dengan nilai UMK lebih dari 3,5 juta rupiah, sedangkan Kabupaten Pangandaran menjadi wilayah dengan UMK paling rendah dengan nilai sebesar UMK 1,4 juta rupiah yang jika dibandingkan dengan tiga kabupaten/kota sebelumnya, maka nilainya tidak mencapai setengahnya. 
Persentase tenaga kerja industri berdasarkan peta tematik di atas menunjukkan persebaran yang lebih menyebar merata jika dibandingkan dengan UMK. Kabupaten Bekasi menjadi wilayah dengan penyerapan tenaga kerja industri paling tinggi daripada wilayah-wilayah lainnya dengan penyerapan sebesar 35 persen. Sedangkan penyerapan terendah berada di Kabupaten Indramayu yang hanya berkisar 6 persen.

Dari peta tematik tersebut persebaran TPAK di Provinsi Jawa Barat juga cenderung menyebar secara acak pada kategori sedang dan rendah. Hanya Kabupaten Pangandaran yang masuk dalam kategori tinggi yang ditandai dengan pola bulatan terbesar yang dikelilingi dengan daerah yang memiliki tingkat TPAK sedang yang ditandai dengan pola bulatan lebih kecil.

\subsection{Faktor yang Mempengaruhi TPT Provinsi Jawa Barat dan Nilai Pengaruhnya}

Langkah awal dalam melakukan analisis spasial adalah melakukan uji Moran I untuk mengetahui ada tidaknya korelasi antarwilayah secara global. Dari hasil uji dapat diketahui bahwa dengan tingkat signifikansi lima persen dapat disimpulkan terdapat autokorelasi spasial atau terdapat unsur ketetanggaan dalam variabel terikat (TPT). Berdasarkan pengujian, nilai autokorelasi Moran bernilai positif yaitu sebesar 0,3311. Nilai Moran positif menunjukkan adanya autokorelasi spasial dengan pola pengelompokan di suatu daerah (Harmes et al., 2017).

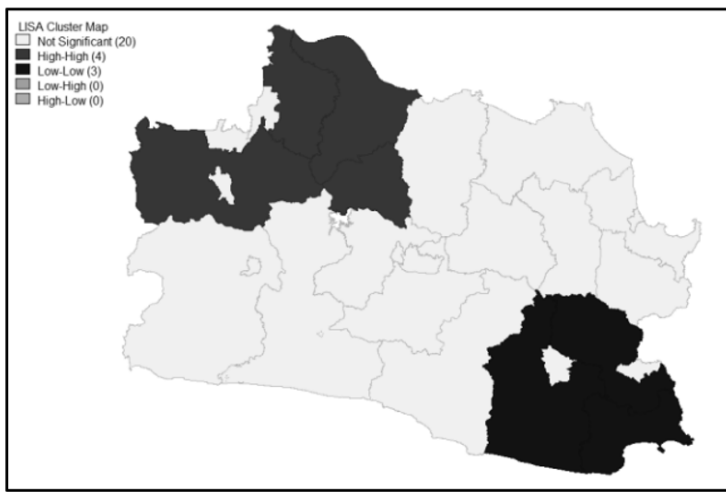

(a)

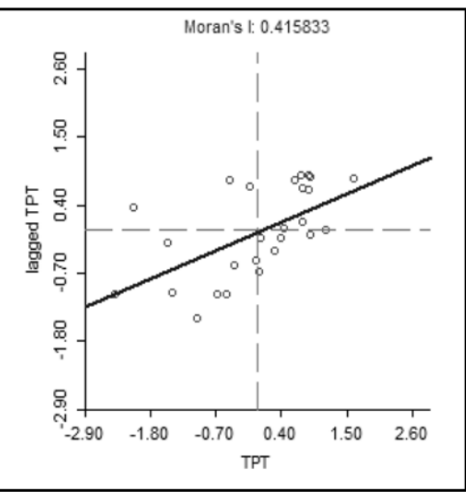

(b)

Gambar 5: LISA Cluster Map (a) dan Moran Scatter Plot (b)

Pengelompokan dapat terjadi di beberapa lokasi yang berbeda. Untuk melihat pengelompokan di suatu lokasi digunakan Local Indicator of Spatial Association (LISA). Dari Gambar 5 (a) terdapat pengelompokan Tingkat Pengangguran Terbuka (TPT) di bagian barat dengan nilai tinggi-tinggi (high-high) yang menandakan 
daerah dengan TPT tinggi dikelilingi oleh daerah yang ada di sekitarnya dengan TPT tinggi pula. Sementara itu, di wilayah bagian timur terdapat pengelompokan dengan nilai rendah-rendah (low-low) yang menandakan daerah dengan TPT rendah dikelilingi oleh daerah yang ada disekitarnya dengan TPT rendah pula. Gambar 5 (b) merupakan grafik Moran scatter plot. Dari scatter plot menunjukkan persebaran data lebih banyak terdapat pada kuadran I dan III. Sedangkan hanya sedikit data yang terdapat pada kuadran II dan IV. Nilai indeks Moran positif yaitu sebesar 0,4158 menunjukkan adanya autokorelasi spasial positif yaitu daerah yang memiliki nilai TPT tinggi dikelilingi oleh daerah dengan yang memiliki nilai TPT tinggi pula dan daerah yang memiliki nilai TPT rendah dikelilingi oleh daerah yang memiliki nilai TPT rendah pula.

Selanjutnya dilakukan uji Langrange Miltiplier untuk melihat jenis ketetanggaan yang terjadi apakah spasial lag model atau Spatial Autoregresive Model (SAR) atau Spatial Error Model (SEM). Hasil uji menunjukkan nilai $0,02<p$-value $(0,05)$ sehingga dengan tingkat signifikansi lima persen unsur ketetanggaan yang terdapat dalam model adalah Spatial Autoregressive Model (SAR) atau spasial lag model. Karena data yang digunakan adalah data panel dengan series 2013-2017, maka perlu dilakukan uji pemilihan model. Dalam hal ini digunakan Uji Hausman untuk menentukan model terbaik antara fixed effect model atau random effect model. Hasil dari uji ini menunjukkan nilai $0,00<p$-value $(0,05)$ sehingga dengan tingkat signifikansi 5 persen fixed effect model lebih baik digunakan daripada random effect model. Oleh karena itu, model spasial panel yang terpilih adalah spasial lag model dengan fixed effect atau fixed effect spatial autoregressive model.

Setelah model terbentuk diperlukan pengujian asumsi klasik (normalitas, non multikolinieritas, dan homoskedastisitas) untuk mengetahui apakah model yang terbentuk dapat digunakan. Berdasarkan Uji Kolmogorov Smirnov diperoleh nilai statistik uji normalitas dengan $p$-value sebesar 0,0739. Sehingga residual model mengikuti distribusi normal. Uji multikolinieritas dilakukan dengan melihat nilai variance inflation factor (VIF). Jika nilai VIF kurang dari 10 maka tidak terdapat multikolineritas. Berdasarkan hasil pengujian diperoleh nilai VIF masing-masing variabel bebas kurang dari 10 sehingga tidak terjadi multikolinearitas. Uji heteroskedastis yang digunakan adalah Uji Glejser. Dari pengujian didapatkan variabel bebas yang digunakan tidak ada yang signifikan dengan nilai lebih besar dari 5 persen. Sehingga asumsi homoskedastis terpenuhi. Asumsi terpenuhi sehingga model yang terbentuk dapat digunakan. Hasil dari estimasi parameter dapat dilihat dalam Tabel 1.

$$
\begin{aligned}
\ln (\widehat{T P T})_{i t}= & 8,66+\hat{\mu}_{i}+0,02 \ln \left(\text { Pert_eko }_{i t}+0,28 \ln (\text { IPM })_{i t}-1,94 \ln (\text { TPAK })_{i t}^{*}\right. \\
& +0,15 \ln (\text { UMK })_{i t}^{*}-0,12 \ln (I D S)_{i t}^{*}+0,25^{*} \sum_{j=1}^{N} w_{i j} u_{i t}
\end{aligned}
$$

Dari hasil estimasi model di atas, nilai $R$-square yang dihasilkan sebesar 0,98 atau sebesar 98 persen. Angka ini memiliki arti sebesar 98 persen variasi TPT di Provinsi Jawa Barat (pada model) dapat dijelaskan oleh variabel-variabel 
Tabel 1: Hasil Estimasi Parameter

\begin{tabular}{lrrr}
\hline Variabel & Koefisien & Standar error & $p$-value \\
\hline$(1)$ & $(2)$ & $(3)$ & $(4)$ \\
\hline Lamda & 0,2497 & 0,0880 & $0,0045^{* *}$ \\
Intercept & 8,6570 & 2,1899 & $0,0000^{* *}$ \\
Ln(Pertumbuhan ekonomi) & 0,0195 & 0,0549 & 0,7215 \\
Ln(IPM) & 0,2761 & 0,3358 & 0,4109 \\
Ln(TPAK) & $-1,9449$ & 0,4506 & $0,0000^{* *}$ \\
Ln(UMK) & 0,1493 & 0,0695 & $0,0316^{*}$ \\
Ln(Share tenaga kerja sektor industri) & $-0,1211$ & 0,0527 & $0,0218^{*}$ \\
\hline R-square & 0,98 \\
Keterangan: ${ }^{*}$ ) signifikan $\alpha=5 \%$ dan ${ }^{* *}$ ) signifikan $\alpha=1 \%$ &
\end{tabular}

yang digunakan. Dari kelima variabel bebas yang digunakan, tingkat partisipasi Angkatan kerja memiliki koefisien terbesar dan bertanda positif. Hal ini menunjukkan bahwa variabel tersebut memiliki kontribusi paling besar dalam mengurangi tingkat pengangguran di Provinsi Jawa Barat daripada variabel bebas lainnya yang digunakan dalam model. Sedangkan IPM memiliki koefisien terbesar dan bertanda positif namun tidak signifikan. Koefisien yang besar menunjukkan bahwa variabel tersebut memiliki kontribusi yang besar terhadap peningakatan kualitas pembangunan manusia. Kondisi seperti ini dapat terjadi karena lapangan pekerjaan tenaga ahli cenderung lebih sedikit. Dari persamaan model di atas dapat diambil contoh model persamaan untuk salah satu wilayah. Dalam hal ini Kota Bandung yang bertetangga dengan Kota Cimahi, Kab. Bandung Barat, dan Kab. Bandung adalah sebagai berikut:

$$
\begin{aligned}
\ln (\widehat{T P T})_{i t}= & 8,65+0,02 \ln (\text { Pert_eko })_{i t}+0,28 \ln (I P M)_{i t} \\
& -1,94 \ln (T P A K)_{i t}^{*}+0,15 \ln (U M K)_{i t}^{*}-0,12 \ln (I D S)_{i t}^{*} \\
& +0,08 u_{\text {Kota Cimahi }}+0,08 u_{\text {Kab Bandung Barat }}+0,08 u_{\text {Kab Bandung }}
\end{aligned}
$$

Berdasarkan persamaan di atas dapat diketahui bahwa meningkatnya TPT masing-masing kabupaten/kota yang menjadi tetangganya akan meningkatkan elastisitas tingkat pengangguran di suatu daerah sebesar 0,08 persen. Nilai 0,08 berasal dari koefisien efek spasial lag $(0,2497)$ dibagi dengan jumlah kabupaten/kota yang menjadi tetangga. Dalam hal ini Kota Bandung memiliki 3 tetangga sehingga nilai spasial lag dibagi 3. Kenaikan TPT di Kabupaten Bandung akan meningkatkan elastisitas tingkat pengangguran di Kota Bandung sebesar 0,08 persen. Angka 8,65 berasal dari konstanta 8,66 pada Tabel 1 ditambah dengan efek individu Kota Bandung sebesar -0,0005 pada Tabel 2. Angka 8,65 bermakna apabila seluruh variabel konstan, maka TPT di Kota Bandung akan lebih tinggi 8,65 persen secara rata-rata TPT kabupaten/kota di Provinsi Jawa Barat.

Tabel 2 merupakan tabel koefisien efek individu dari masing-masing kabupaten/kota. Efek individu tersebut jika bernilai positif memiliki makna apabila seluruh variabel konstan maka nilai TPT secara rata-rata akan lebih tinggi da- 
Tabel 2: Efek Individu Kabupaten/kota

\begin{tabular}{clr}
\hline No. & Kabupaten/kota & Efek individu \\
\hline$(1)$ & $(2)$ & $(3)$ \\
\hline 1 & Bogor & 0.0105136 \\
2 & Sukabumi & -0.0739252 \\
3 & Cianjur & -0.1376181 \\
4 & Bandung & -0.0885656 \\
5 & Garut & -0.0137600 \\
6 & Tasikmalaya & 0.0835350 \\
7 & Ciamis & 0.0470556 \\
8 & Kuningan & 0.0232371 \\
9 & Cirebon & -0.0592705 \\
10 & Majalengka & 0.0254346 \\
11 & Sumedang & -0.0971242 \\
12 & Indramayu & -0.0456056 \\
13 & Subang & 0.1026992 \\
14 & Purwakarta & 0.1132957 \\
15 & Karawang & 0.0399654 \\
16 & Bekasi & -0.0769256 \\
17 & Bandung Barat & 0.0356401 \\
18 & Pangandaran & -0.0464594 \\
19 & Kota Bogor & 0.0679764 \\
20 & Kota Sukabumi & 0.2408056 \\
21 & Kota Bandung & -0.0058071 \\
22 & Kota Cirebon & -0.2181103 \\
23 & Kota Bekasi & 0.0364411 \\
24 & Kota Depok & 0.0395866 \\
25 & Kota Cimahi & -0.0513509 \\
26 & Kota Tasikmalaya & 0.0449643 \\
27 & Kota Banjar & 0.0033721 \\
\hline & &
\end{tabular}

ripada daerah lain, sedangkan jika bernilai negatif memiliki makna nilai TPT secara rata-rata akan lebih rendah dari daerah lain. Salah satu contohnya Kota Cirebon yang memiliki nilai efek individu terkecil yaitu sebesar -0,21811. Sehingga secara rata-rata Kota Cirebon memiliki nilai TPT yang paling rendah daripada kabupaten/kota lain.

Tingkat pertumbuhan ekonomi yang dilihat dari laju PDRB tidak berpengaruh signifikan terhadap TPT di Provinsi Jawa Barat dan bertanda positif. Artinya setiap peningkatan pertumbuhan ekonomi akan meningkatkan tingkat pengangguran. Hasil ini tidak sesuai dengan Hukum Okun (Okun's Law) dimana seharusnya pertumbuhan ekonomi memiliki hubungan yang berlawanan dengan tingkat pengangguran. Hal ini bisa terjadi karena pertumbuhan ekonomi yang belum merata di Provinsi Jawa Barat. Jika dilihat dari peta tematik, pertumbuhan ekonomi memiliki persebaran yang menyebar secara acak sedangkan tingkat pengangguran memiliki pola perbesaran yang mengelompok.

Indeks Pembangunan Manusia (IPM) tidak berpengaruh signifikan terhadap tingkat pengangguran di Pulau Jawa dan bertanda positif. Sehingga peningkatan IPM akan menyebabkan tingkat pengangguran di Provinsi Jawa Barat meningkat. Menurut Choirunnisa (2018), hal ini disebabkan karena pembangunan fasilitas 
pendidikan, kesehatan yang kurang merata ataupun pembangunan di kota lebih cepat berkembang. Jika dilihat dari peta tematik, nilai IPM di kota lebih tinggi daripada di kabupaten. Hubungan tingkat pengangguran dengan IPM bernilai positif dapat dikarenakan adanya penciptaan lapangan pekerjaan baru yang tidak sesuai dengan sumber daya manusia yang dimiliki.

Tingkat Partisipasi Angkatan Kerja (TPAK) berpengaruh signifikan terhadap tingkat pengangguran Provinsi Jawa Barat dan bertanda negatif. Tanda yang negatif menunjukkan bahwa ketika TPAK mengalami peningkatan menyebabkan tingkat pengangguran di Provinsi Jawa Barat akan berkurang. Hal ini sejalan dengan gambaran dari peta tematik yaitu TPAK yang tinggi pada umumnya tersebar di wilayah yang memiliki tingkat pengangguran yang rendah. Hasil tersebut sejalan dengan penelitian Astuti et al. (2017) yang melakukan studi kasus analisis faktor yang berpengaruh terhadap tingkat pengangguran terbuka di Provinsi Jawa Timur menggunakan regresi data panel.

Upah Minimum Kabupaten (UMK) berpengaruh signifikan terhadap tingkat pengangguran Provinsi Jawa Barat dan bertanda positif. Hasil ini sesuai dengan penelitian dari Panjawa dan Soebagiyo (2014). Tanda positif menunjukkan saat terjadi kenaikan pada UMK akan meningkatkan tingkat pengangguran di Provinsi Jawa Barat. Hal ini sesuai dengan hubungan antara upah dan tenaga kerja dalam Borjas (2013) dimana saat upah minimum meningkat, permintaan terhadap tenaga kerja menurun, sedangkan dari sisi penawaran tenaga kerja terjadi peningkatan sehingga selisih antara permintaan dan penawaran ini akan menyebabkan pengangguran. Wilayah yang memiliki nilai UMK dan TPT yang tinggi disebabkan wilayah tersebut memiliki daya tarik besar dalam pencarian kerja karena nilai upahnya yang tinggi. Sehingga banyak pencari kerja yang tertarik untuk datang ke wilayah tersebut.

Persentase tenaga kerja sektor industri berpengaruh negatif dan signifikan terhadap tingkat pengangguran di Provinsi Jawa Barat. Tanda negatif dalam koefisien menunjukkan bahwa meningkatnya persentase tenaga kerja dalam sektor industri akan mengurangi tingkat pengangguran di Provinsi Jawa Barat. Penelitian dari Karaalp-Orhan dan Gülel (2016) juga memiliki kesamaan dimana pengangguran memiliki hubungan yang negatif dengan persentase tenaga kerja sektor industri. Hubungan yang negatif ini dapat terjadi karena adanya kemajuan teknologi yang mendorong perubahan struktur ekonomi dari pertanian menjadi industrialisasi.

\section{Kesimpulan dan Saran}

\subsection{Kesimpulan}

Berdasarkan hasil dan pembahasan dari analisis di atas, maka dapat diambil kesimpulan sebagai berikut:

- Dari uji spasial diperoleh hasil bahwa terdapat pengelompokan Tingkat Pengangguran Terbuka (TPT) di bagian barat dengan nilai tinggi-tinggi 
(high-high) yang menandakan daerah dengan TPT tinggi dikelilingi dengan daerah yang ada di sekitarnya dengan TPT tinggi pula. Daerah tersebut antara lain: Bekasi, Bogor, Karawang, dan Purwakarta. Sementara itu, di wilayah bagian timur terdapat pengelompokan dengan nilai rendah-rendah (low-low) yang menandakan daerah dengan TPT rendah dikelilingi daerah yang ada di sekitarnya dengan TPT rendah pula. Daerah tersebut antara lain: Tasikmalaya, Ciamis, dan Pangandaran.

- Berdasarkan analisis yang dilakukan dengan metode analisis regresi panel spasial, didapatkan variabel-variabel yang memengaruhi tingkat pengangguran kabupaten/kota di Provinsi Jawa Barat antara lain: TPAK, UMK, dan persentase tenaga kerja sektor industri.

- Pertumbuhan ekonomi dan IPM tidak berpengaruh signifikan terhadap pengangguran menunjukkan pembangunan ekonomi yang belum merata dan penciptaan lapangan pekerjaan yang kurang sesuai dengan sumber daya manusia.

\subsection{Saran}

Berdasarkan kesimpulan diatas, maka saran yang diberikan peneliti adalah sebagai berikut:

- Pemerintah Provinsi Jawa Barat hendaknya meningkatkan pemerataan antarwilayah dan memaksimalkan setiap kabupaten/kota Provinsi Jawa Barat sesuai dengan potensi dan kondisi geografisnya yang dimiliki sehingga mengurangi tingkat pengangguran. Peningkatan tersebut dapat didukung dengan adanya infrastruktur publik yang menghubungkan antar wilayah dengan disertai penciptaan lapangan kerja pada wilayah yang masih memiliki tingkat upah yang rendah, sehingga dapat menarik pencari kerja yang tidak dapat bersaing di daerah yang memiliki tingkat upah lebih tinggi.

- Perlu ada kebijakan pemerintah daerah seperti yang diterapkan di Kabupaten Bandung yang dapat menurunkan tingkat penganggurannya secara signifikan yaitu dapat berupa program-program pelatihan kerja yang dapat menyerap tenaga kerja baru ataupun kemudahan pinjaman untuk pelaku usaha untuk mengurangi pengangguran.

- Persentase tenaga kerja sektor industri berpengaruh signifikan terhadap pengurangan tingkat pengangguran di Provinsi Jawa Barat, pemerintah dapat mempertimbangkan pembukaan lapangan pekerjaan di sektor industri padat karya.

\section{Daftar Pustaka}

[1] Althofia, N. Y., \& Agustina, N. (2015). Pengaruh pengeluaran pemerintah untuk pendidikan, kesehatan, dan infrastruktur terhadap PDRB dan penyerapan tenaga kerja di Propinsi Jawa Barat tahun 2012. Jurnal Aplikasi Statistika \& Komputasi Statistik, 7(1), 1-20. doi: https://doi.org/10.34123/jurnalasks.v7i1.118. 
[2] Astuti, W. I., Ratnasari, V., \& Wibowo, W. (2017). Analisis Faktor yang Berpengaruh Terhadap Tingkat Pengangguran Terbuka di Provinsi Jawa Timur Menggunakan Regresi Data Panel. Jurnal Sains dan Seni ITS, 6(1), D144-D149. doi: 10.12962/j23373520.v6i1.22977.

[3] Borjas, G. J. (2013). Labor economics (6th Edition). New York: McGraw Hill.

[4] BPS. (2018a). Provinsi Jawa Barat dalam Angka 2018. Jakarta: Badan Pusat Statistik.

[5] BPS. (2018b). Statistik Indonesia 2018. Jakarta: Badan Pusat Statistik.

[6] Choirunnisa, M. (2018). Analisis panel spasial tingkat pengangguran terbuka di Kalimantan Timur tahun 2011-2015. Jakarta: Sekolah Tinggi Ilmu Statistik.

[7] Harmes, H., Juanda, B., Rustiadi, E., \& Barus, B. (2017). Pemetaan efek spasial pada data kemiskinan Kota Bengkulu. Journal of Regional and Rural Development Planning, 1(2), 192-201. doi: https:/ / doi.org/10.29244/jp2wd.2017.1.2.192-201.

[8] Isnayanti, N. D., \& Ritonga, A. (2017). Analisis faktor-faktor yang mempengaruhi tingkat pengangguran di Provinsi Sumatera Utara tahun 1978-2014 dengan metode ordinary least square. Karismatika: Kumpulan Artikel Ilmiah, Informatika, Statistik, Matematika dan Aplikasi, 3(2), 180-197. DOI: https://doi.org/10.24114/jmk.v3i2.8809.

[9] Jurajda, Š., \& Terrell, K. (2009). Regional unemployment and human capital in transition economies. Economics of Transition, 17(2), 241-274. doi: https://doi.org/10.1111/j.1468-0351.2009.00351.x.

[10] Karaalp-Orhan, H. S., \& Gülel, F. E. (2016). Regional unemployment in Turkey: A spatial panel data analysis. Journal of Social Security, 6(2), 47-67.

[11] Mahihody, A. Y., Engka, D. S., \& Luntungan, A. Y. (2018). Pengaruh upah dan Indeks Pembangunan Manusia (IPM) terhadap pengangguran di Kota Manado. Jurnal Berkala Ilmiah Efisiensi, 18(3), 24-34.

[12] Martin, P., \& Ottaviano, G. I. P. (2001). Growth and agglomeration. International Economic Review, 42(4), 947-968. doi: https://doi.org/10.1111/1468-2354.00141.

[13] Panjawa, J. L., \& Soebagiyo, D. (2014). Efek peningkatan upah minimum terhadap tingkat pengangguran. Jurnal Ekonomi \& Studi Pembangunan, 15(1), 48-54.

[14] Shekhar, S, Xiong, H., \& Zhou, X. (Eds.) (2017). Encyclopedia of GIS (2nd edition). Switzerland: Springer International Publishers.

[15] Sukirno, S. (2006). Ekonomi pembangunan proses: Masalah dan dasar kebijakan (Edisi 2). Jakarta: Kencana Prenada Media Grup. 
this page intentionally left blank 